\title{
Out of hours primary care
}

\author{
Variable service provision means inequalities in access and care
}

See pp 182, 187, 190, 193, 198, 199
$\mathrm{T}$

The six papers on out of hours care published in this week's $B M J$ highlight the increasing variability in primary care services available to patients outside normal surgery hours. Variations in the quality and acceptability of care provided by deputising services and general practitioner rotas have long caused concern, ${ }^{1}$ but a third provider group has now entered the arena. General practitioner cooperatives have mushroomed, fuelled by general practitioners' dissatisfaction with rota commitments and financial support from the government. ${ }^{23}$ Unlike commercial services, ${ }^{4-6}$ cooperatives do not face external controls and, as Jessopp and colleagues point out (p 199), ${ }^{7}$ they vary widely in their composition and patterns of service delivery.

Giving telephone advice alone is increasingly common. Cragg and colleagues' data from 1994-5 (p 187) show that less than $1 \%$ of callers to four deputising services and $20 \%$ of callers to general practitioner rotas received telephone advice, ${ }^{8}$ which contrasts sharply with Salisbury's data for 1996, with rates of 19\% for deputising service contacts and $58 \%$ for a general practitioner cooperative (p 182). ${ }^{9}$ While it would be unwise to place too much reliance on figures from one metropolitan cooperative, Jessopp and colleagues report rates of telephone advice between $10 \%$ and $65 \%$ across 67 cooperatives, with a median of $38 \%{ }^{7}$

Is this a cause for concern? It is clear that clinical criteria alone do not govern the nature of the response to patients' calls and that widely differing standards of access to a doctor now obtain. In 1987, when Marsh and colleagues reported handling $59 \%$ of out of hours calls to their own practice rota by telephone advice alone, ${ }^{10}$ this was considered sufficiently alarming to generate columns of correspondence in subsequent issues of the $B M J$, questioning the safety and standard of care provided. In a 1992 survey of telephone use in general practice, a substantial proportion of general practitioners expressed personal disquiet with this form of care, particularly when they did not know the patient. ${ }^{11}$ Yet telephone advice is now being offered increasingly often by deputising services and by large groups of general practitioners in cooperatives with consequently less personal knowledge of the patients they are advising and the communities in which they are working. Previously expressed concerns seem to have evaporated, and the potential role of practice nurses in providing telephone triage is now being studied (p 198). ${ }^{12}$
A new and reliable measure of patient satisfaction with out of hours care, developed by McKinley and colleagues ( $p$ 193), ${ }^{13}$ has shown higher levels of dissatisfaction than ever previously reported (p 190). ${ }^{14}$ The authors are right to point out that direct comparisons between these findings and those of earlier studies using less well designed and tested measures are not possible, but the levels are striking in themselves, and once again deputising services score less well than general practitioner rotas. Patient satisfaction has been shown in the past to be related to speed of response, ${ }^{15} 16$ and this remains the aspect of care with which patients are least satisfied. Yet response times are slowing generally and seem to be poorest in the cooperative studied by Salisbury. ${ }^{9}$ Cragg et als median response times of 35 minutes for rota general practitioners and 52 minutes for deputising doctors ${ }^{8}$ contrast with Salisbury's 65 minutes for deputising doctors and 75 minutes for the cooperative. ${ }^{9}$

More research is needed on the ability of cooperatives to respond rapidly in cases of urgent need. Many rural cooperatives cover large geographical areas. Outside the periods of peak demand a single general practitioner may be responsible for providing telephone advice, centre based consultations, and home visits. In some cases, call handling services introduce an added delay between patients' calls and a general practitioner's response. This issue does not simply relate to patient satisfaction but also to patient safety.

In 1992 a stage had been reached at which the demands and expectations of patients for out of hours care had outstripped general practitioners' willingness and ability to meet them. Increased reliance on deputising services and the growth of the cooperatives has averted an immediate crisis. However, out of hours services are now more variable, and it is by no means clear to what extent that variability represents inequality in access, quality of care, and hence satisfaction with services. McKinley and colleagues' measure of patient satisfaction will be a valuable tool in assessing the impact of new methods of organising and delivering services on patient satisfaction. ${ }^{12}$

We have not yet accumulated a sufficient body of evidence to judge the quality of services offered by cooperatives. As Jessopp and colleagues show, ${ }^{7}$ their enthusiasm for centre based care (5-70\% of contacts) in preference to home visiting is as variable as their reliance on telephone advice and equally unevaluated. The benefits they offer their general practitioner members have been widely quoted, ${ }^{17}$ but they have spread 
without reference to patients' views, with no attempt to involve users in their planning and operation, and with limited efforts to assess patient satisfaction. Without evidence to support a need for uniform standards of service and care, and without a clear idea of what those standards should be, they are likely to maintain their independence of action, as practice rotas have always done.

Uniformity is not necessarily a virtue in circumstances where needs and demands for care differ. The importance of flexibility in order to address local needs and circumstances, particularly where services are poor, lies at the heart of the recent government white paper on primary care. ${ }^{18}$ However, equality of access to uniformly high standards of care is an important goal for primary health care, and increasing variability in the organisation and delivery of out of hours services should not lead to increasing inequality.

Lesley Hallam Research fellow

National Primary Care Research and Development Centre,

University of Manchester,

Manchester M13 9PL

1 Hallam L. Primary medical care outside normal working hours: review of published work. BMJ 1994;308:249-53.

2 General Medical Services Committee. Your choices: special report. London: GMSC, 1992.
3 Hurwitz B. The new out of hours agreement for general practitioners. BMJ 1995;311:824.

4 Department of Health and Social Security. General practitioner deputising services. London: DHSS, 1984. (Health Circular (FP) 84.)

5 Department of Health and the Welsh Office. General practice in the National Health Service: a new contract. London: HMSO, 1989.

6 Cragg D, Hallam L. Quality standards for deputising services. BMJ 1994;309:1630.

7 Jessopp L, Beck I, Hollins L, Shipman C, Reynolds M, Dale J. Changing the pattern of out of hours: a survey of general practice cooperatives. $B M J$ 1997;314:199-200

8 Cragg DK, McKinley RK, Roland MO, Campbell SM, Van F, Hastings AM, et al. Comparison of out of hours care provided by patients own general practitioners and commercial deputising services: a randomised controlled trial. I: The process of care. BMJ 1997;314:187-9.

9 Salisbury C. Observational study of a general practice out of hours cooperative: measures of activity. BMJ 1997;314:182-6.

10 Marsh GN, Horne RA, Channing DA. A study of telephone advice in managing out-of-hours calls. J $R$ Coll Gen Pract 1987;37:301-4.

11 Hallam L. Patient access to general practitioners by telephone: the doctor's view. BrJ Gen Pract 1992;42:186-9.

12 South Wiltshire Out of Hours (SWOOP) Group. Nurse telephone triage in out of hours primary care: a pilot study. BMJ 1997;314:198-9.

13 McKinley RK, Manku-Scott TK, Hastings AM, French DP, Baker R. Reliability and validity of a new measure of patient satisfaction with out of hours primary medical care in the United Kingdom: development of a patient questionnaire. BMJ 1997;314:193-8.

14 McKinley RK, Cragg DK, Hastings AM, French DP, Manku-Scott TK, Campbell SM, et al. Comparison of out of hours care provided by patients' own general practitioners and commercial deputising services: a randomised controlled trial.II: The outcome of care. BMJ 1997;314:190-3

15 Sawyer L, Arber S. Changes in home visiting and night and weekend cover: the patients' view. BMJ 1982;284:1531-4.

16 Dixon RA, Williams BT. Patient satisfaction with general practitioner deputising services. $B M J$ 1988;297:1519-122.

17 Reynolds M. Why run GP co-ops? Pulse 1995 March 11:48.

18 Secretaries of State for Health, Wales and Scotland. Choice and opportunity. Primary care: the future. London: HMSO, 1996.

\title{
Epilepsy: getting the diagnosis right
}

\author{
All that convulses is not epilepsy
}

$\mathrm{E}$ pilepsy may present with a variety of symptoms, and other conditions may mimic its manifestations. The diagnosis is almost always based solely on the clinical history. It is therefore not surprising that diagnostic accuracy remains a major problem. ${ }^{1}$ About a fifth of patients referred to specialist units with "intractable epilepsy" are found, on further assessment, not to have epilepsy. It is also common for patients to have symptoms for months or even years before epilepsy is diagnosed. Thus, it is important to be aware of both the heterogeneous and sometimes subtle forms of epilepsy and of the alternative diagnoses. ${ }^{3}$

The differential diagnosis of epilepsy includes all causes of transient loss of awareness, falls, paroxysmal sensory-motor phenomena, and generalised convulsive movements which are the most common presenting symptom of epilepsy. ${ }^{3}$ Tonic-clonic seizures ("a convulsion") start with sudden loss of awareness, a guttural cry, generalised stiffening of the body and limbs, followed by rhythmic jerking of the limbs, often associated with tongue biting and urinary incontinence. The convulsive movements usually last for at most one to two minutes, and, as the attack proceeds, the jerking slows in frequency and increases in amplitude. There is often cyanosis and irregular breathing followed by confusion, headache, and drowsiness. Tonic-clonic seizures may sometimes be preceded by myoclonic jerks in idiopathic generalized epilepsy or by a simple partial seizure ("aura") in partial epilepsy. When all or most of these features are reported there is little room for diagnostic confusion. ${ }^{3}$

However, other conditions may present with similar phenomena. If misinterpreted, these can lead to unnecessary treatment and social and occupational handicap. The most common sources of confusion are vasovagal syncope and non-epileptic attacks of a psychological origin. Syncope is often misdiagnosed, as it may be accompanied by brief stiffening or jerking of the extremities, and consequently is liable to be reported as a convulsion by witnesses. A video study of syncope induced in healthy volunteers has shown that multifocal and generalised myoclonic jerks are common in syncope. ${ }^{4}$ However, syncope can usually be correctly identified by the presence of precipitating factors and prodromal symptoms. Syncope often occurs on prolonged standing or when rising quickly, particularly if associated with peripheral vasodilatation. Syncope is unusual when recumbent, unless it is of cardiac origin. Fright, painful stimuli, cough, and micturition (particularly in older people) may also be triggers. Syncopal attacks are preceded by a feeling of lightheadedness, dizziness, nausea, ringing in the ears, and the vision "going grey"-features that are rare in epilepsy. Incontinence is rare, and recovery of consciousness usually occurs within a minute. ${ }^{3}$

Non-epileptic attack disorder may be characterised by semi-purposeful thrashing of all four limbs that waxes and wanes in intensity over many minutes, and 
some patients exhibit prominent pelvic movements and back arching, often with evidence of retained awareness. ${ }^{2}$ Recovery is variable and may be much quicker than expected from the duration of the attack. ${ }^{3}$

In this week's BMJ, McCrory and colleagues describe what they call "concussive convulsion," (p 171) another potential pitfall in the diagnosis of epilepsy. ${ }^{5}$ Convulsions that occur within seconds of an impact to the head have been widely assumed to represent a form of post-traumatic epileptic seizure, but McCrory and colleagues suggest that these are a non-epileptic phenomenon. Studying a series of 22 well documented attacks, some captured on video, that occurred after minor head trauma during Australian football, the authors were able to ascertain the benign nature of these attacks. The convulsions occurred within two seconds of the impact and resembled tonic-clonic seizures. The convulsions were usually brief, but some lasted for over two minutes. Recovery was quick; indeed, in two cases the players were alert and oriented within seconds of the convulsive event. Of particular importance is that, after a mean follow up of 3.5 years, no subjects developed epilepsy. This corroborates Jennett's observation over 20 years ago that seizures confined to the time of the head injury are not associated with subsequent epilepsy. ${ }^{6}$

The clinical characteristics of concussive convulsions seem to differ somewhat from those after syncope. There is a more prominent tonic phase, and the attack lasts longer. Electroencephalography shows that syncopal convulsions are non-epileptic, but it remains to be established whether these events arise as a result of an epileptic discharge. McCrory et al argue that they do not. Alternatively, we suggest that they represent an acute symptomatic but benign seizure. Pathophysiology notwithstanding, the observations provide helpful prognostic information. Concussive convulsions should be distinguished from seizures that occur within the first week of head injury rather than instantly after impact. These carry a $25 \%$ risk of later epilepsy. ${ }^{6}$

Every effort should be made to reach a firm diagnosis in cases of possible epilepsy. If doubt remains after the first event it is usually wise to await further events and reach a secure diagnosis, rather than initiate anti-epileptic treatment prematurely.

J W A S Sander Senior lecturer M F O'Donoghue Research fellow

Institute of Neurology,

National Hospital for Neurology and Neurosurgery,

Queen Square,

London WC1N 3BG

Sander JWAS, Shorvon SD. The epidemiology of the epilepsies. J Neurol Neurosurg Psychiatr 1996;61:433-4.

Lesser R. Psychogenic seizures. Neurology 1996;46:1499-507.

3 Duncan JS. Diagnosis-Is it epilepsy? In:Duncan JS, Shorvon SD, Fish DR. Clinical epilepsy. Edinburgh: Churchill Livingstone, 1995:1-23.

Lempert T, Bauer M, Schmidt D. Syncope: a videometric analysis of 56 episodes of transient cerebral hypoxia. Neurology 1994;36:233-7.

5 McCrory PR, Bladin PF, Berkovic SF. Concussive convulsions: phenomenology, aetiology and outcome. BMJ 1997;314:171-4.

6 Jennett B. Epilepsy after non-missile head injury. London: Heinemann, 1975.

\section{Lack of oats toxicity in coeliac disease}

\section{Toxic fraction makes up less of total protein than in other cereals}

I $\mathrm{n}$ his pioneering study of "the harmful effects of certain types of cereal on patients suffering from coeliac disease," Dicke showed that wheat and rye could reproducibly trigger anorexia, diarrhoea, and steatorrhoea in these patients. ${ }^{1}$ Soon after, using the same prolonged fecal balance studies, Dicke found that oats were also noxious whereas corn, rice, and potatoes were not. ${ }^{2}{ }^{3}$ Reports suggesting that barley was toxic came later. ${ }^{4}$ Simultaneously, the "injurious constituent of wheat" was found to be its prolamin (or alcohol soluble protein), gliadin. ${ }^{3}$ Secalin, hordein, and avenin, the prolamins of rye, barley, and oats respectively, were thus considered as the toxic fractions of these cereals.

However, whereas the noxious effects of wheat, barley, and rye could be reproduced, the harmful effects of oats remained controversial-observed by some workers, ${ }^{23}$ denied by others, ${ }^{6}{ }^{7}$ and variable for still others. ${ }^{58}$ This uncertainty stems from several factors. Firstly, the early studies included small numbers of patients (from two to 12) and followed them for short periods (from several weeks to less than three months). Secondly, the methods used to determine the harmful effects varied from insensitive functional tests-balance studies $^{238}$ and xylose tests $^{5}$ - to histological ${ }^{4}$ and biochemical studies ${ }^{7}$ of small intestinal biopsies that were sometimes difficult to interpret. These methodological limitations are relevant when considering the variability of gluten sensitivity from patient to patient; several years of a gluten containing diet are sometimes necessary before a patient will relapse. ${ }^{9}$ However, despite the variability of the clinical and histological responses observed after these early challenges with oats, it seems clear that taking small amounts of oats (about $50 \mathrm{~g}$ ) for short periods (less than one month) is not generally noxious whereas more than $100 \mathrm{~g}$ for longer than a month leads to recurrence of steatorrhoea, a strong sign of serious mucosal damage. ${ }^{23} 8$

A recent Finnish study avoided the pitfalls of variability by following a large number of patients (92) for one year and using stringent histological criteria of mucosal damage. Patients recently diagnosed or in remission were given a gluten free diet and randomised to receive either no oats or $50 \mathrm{~g}$ of oats a day. Severe cases were excluded. After one year, the two groups showed no significant difference in clinical symptoms, laboratory measures, or histological criteria. All the newly diagnosed patients were in clinical and histological remission. The conclusion is straight- 
forward: moderate amounts of oats (40-60 g/day) are not toxic in most patients with coeliac disease. ${ }^{10}$

The recent study by Srinivasan et al points in the same direction. ${ }^{11}$ Ten patients, including two who were particularly sensitive to gluten, consumed $50 \mathrm{~g}$ of oats as porridge daily for three months while maintaining a strict gluten free diet. During the challenge the patients remained symptom free and maintained low titres of antiendomysium and antiangliadin antibodies. Quantitative histological evaluation at the end of the observation period showed no change in mucosal appearance, in particular no increase in intraepithelial lymphocyte count. Thus, as in the Finnish study, although with a smaller number of patients and shorter duration of challenge, moderate amounts of oats proved non-toxic. These findings have recently been confirmed in patients with dermatitis herpetiformis, ${ }^{12}$ and in the case of the Finnish study, by a five year follow up. ${ }^{13}$

Although concordant, these studies do not show that larger daily amounts of oats (100-160 g) would be equally non-toxic in these patients. Indeed, as suggested by the early experiments, ${ }^{238}$ large amounts of oats are theoretically likely to be toxic. The oat is a member of the Avena tribe, whereas wheat, rye, and barley are members of the neighbouring Triticeae tribe, both tribes being part of the Pooideae subfamily. Thus, avenin, the prolamin of oats, is genetically less like gliadin than are secalin and hordein. Despite this greater difference, sequence homologies (and weak immunological cross reactivity) have been found between avenin and the prolamins from barley, wheat, and rye. ${ }^{14-16}$ Moreover, avenin accounts for only 5-15\% of the total protein in oats compared with the $40 \%$ contribution from gliadin in wheat and the prolamins in rye and barley. ${ }^{14}$ Thus, taking into account a smaller number of toxic sequences per unit weight of avenin and the smaller amounts of avenin as a proportion of the oat seed proteins, it seems likely that only considerable amounts of oats consumed over long periods will be toxic for patients with coeliac disease.

However, until randomised studies are performed on large enough numbers of patients consuming large amounts of oats for long periods, it seems reasonable to assume that moderate amounts of oats may be consumed by most patients without risk. ${ }^{10}{ }^{11}$ As noted by
Watson, ${ }^{17}$ in Scotland "it would have been obvious many years ago if coeliac children and adults who are taking porridge relapsed."

Jacques Schmitz Professor

Gastro-Entérologie Pédiatrique,

Hôpital des Enfants Malades,

149 rue de Sèvres,

75743 Paris Cedex 15

France

1 Dicke WK. Coeliac disease. Investigation of the harmful effects of certain types of cereal on patients suffering from coeliac disease. MD thesis. Utrecht University: Utrecht, Netherlands , 1950.

2 Dicke WK, Weijers HA, van de Kamer JH. Coeliac disease II. The presence in wheat of a factor having a deleterious effect in cases of coeliac disease. Acta Paediatr 1953;42:34-42.

3 Van de Kamer JH, Weijers HA, Dicke WK. Coeliac disease IV. An investigation into the injurious constituents of wheat in connection with their action on patients with coeliac disease. Acta Paediatr 1953;42:223-31.

4 Rubin CE, Brandborg LL, Flick Al, Phelps P, Parmentier C, van Niel S. Studies of celiac sprue. III. The effect of repeated wheat instillation into the proximal ileum of patients on a gluten free diet. Gastroenterology the proximal ile

5 Baker PG, Read AE. Oats and barley toxicity in coeliac patients. Postgrad Med J 1976;52:264-8.

6 Sheldon W. Coeliac disease (in regard to gluten intolerance). Lancet 1955;ii:1097-2001.

7 Dissanayake AS, Truelove SC, Whitehead R. Lack of harmful effect of oats on small-intestinal mucosa in coeliac disease. BMJ 1974;iv:189-91.

8 Moulton ALC. The place of oats in the coeliac diet. Arch Dis Child 1959;34:51-5.

9 McNicholl B, Egan-Mitchell B, Fottrell PF. Variability of gluten intolerance in treated childhood coeliac disease. Gut 1979;20:126-32.

10 Janatuinen EK, Pikkarainen PH, Kemppainen TA, Kosma VM, Järvinen RMK, Uusitupa MIJ, et al. A comparison of diets with and without oats in adults with celiac disease. $N$ Engl J Med 1995;333:1033-7.

11 Srinivasan U, Leonard N, Jones E, Kasarda DD, Weir DG, O'Farrelly C, et al. Absence of oats toxicity in adult coeliac disease. BMJ 1996;313:1300-1. 12 Reunala T, Collin P, Puolakka T, Vuolteenaho N, Miettinen A, Pikkarainen $\mathrm{P}$, et al. Oats for patients with dermatitis herpetiformis? Seventh International Symposium on Coeliac Disease, Tampere, Finland, September 5-7. 1996.

13 Janatuinen E, Kemppainen T, Kosma V-M, Heikkinen M, Julkunen R, Uusitupa M. Oats in coeliac diet; a 5-year follow-up study. Seventh International Symposium on Coeliac Disease, Tampere, Finland, September 5-7. 1996.

14 Shewry PR, Tatham AS, Kasarda DD. Cereal proteins and coeliac disease. In: Marsh MN, ed. Coeliac disease. Oxford: Blackwell Scientific, 1992:30548.

15 Troncone R, Auricchio S, De Vincenzi M, Donatiello A, Farris E, Silano V. An analysis of cereals that react with serum antibodies in patients with coeliac disease. J Pediatr Gastroenterol Nutr 1987;6:346-50.

16 Freedman AR, Galfre G, Gal E, Ellis HJ, Ciclitira PJ. Western immunoblotting of cereal proteins with monoclonal antibodies to wheat gliadin to investigate coeliac disease. Int Archs Allergy Appl Immunol $1988 ; 85: 346-50$

17 Van de Kamer JH, Weijers HA, Wauters EA. Some biochemical aspects of coeliac disease: past, present and future. In: Brooth CC, Dowling RH, eds. Coeliac disease. London: Churchill Livingstone, 1970:106-14.

\section{Hysterectomy: will it pay the bills in 2007?}

\section{Treatment of choice for cancer, but a choice of treatment for menorrhagia}

$\mathrm{T}$ o study the indications for hysterectomy is to study the interface between medicine and society. In California barely half of all women will carry their uterus to the grave, ${ }^{1}$ whereas a gynaecologist in Saudi Arabia may do no more than one hysterectomy a year and, as often as not, this will be a lifesaving operation for catastrophic obstetric haemorrhage. In Britain hysterectomy rates are somewhere between these two extremes. To understand the variations, do not gaze endlessly at histological specimens but examine the societies from which they originate.
Perceived abnormal bleeding acounts for $70 \%$ of hysterectomies in pre-menopausal British women, and in most cases of "menorrhagia," menstrual blood loss is within the "normal" range. ${ }^{2}$ Much of the variation in hysterectomy rates is therefore attributable to the psychosocial factors that influence demand. ${ }^{3}$

Provider factors are also important. Women general practitioners are less likely than their male counterparts to refer women with menstrual symptoms for a specialist opinion; ${ }^{4}$ and hysterectomy, like cholecystectomy and tonsillectomy, varies considerably in frequency from surgeon to surgeon. ${ }^{5}$ This is not to 
say that gynaecologists exploit women for personal gain or take some sort of covert delight in the procedure; doctors' wives, after all, undergo hysterectomy as often as controls matched for social class. ${ }^{6}$ Yet hysterectomy rates are not only variable but labile: a public education campaign in the Italian speaking cantons of Switzerland resulted in a sharp fall in hysterectomy rates compared with the control cantons (French and German speaking). ${ }^{7}$

It is tempting to conclude that a lot of unnecessary surgery is going on and that we should campaign against it. But what are the effects of hysterectomy? Although in the short term women who have had a hysterectomy score worse than non-surgical controls on measures of wellbeing, if the same women are followed prospectively their scores improve. ${ }^{8}$ An authoritative study failed to confirm fears that hysterectomy increases the risk of urinary incontinence. ${ }^{9}$ And while hysterectomy is a major operation with serious morbidity and, very rarely, mortality ${ }^{10}$ it may also save lives by reducing the risk of uterine cancer. The relative risks of operative mortality and death from cancer are such that hysterectomy is the safer option. ${ }^{11}$ Risk of cancer is reduced still further by removing the ovaries, although this increases the risk of ischaemic heart disease unless hormone replacement therapy is taken. However, oestrogen replacement does not correct the loss of libido that follows oophorectomy, perhaps as a result of androgen deficiency. ${ }^{8}$ Preliminary evidence that hysterectomy may predispose to ovarian failure, even when the ovaries are conserved, is a subject of current research.

How should hysterectomy be performed? Vaginal hysterectomy is associated with fewer complications than abdominal hysterectomy. ${ }^{12}$ However, this has not been confirmed by a recent systematic review, ${ }^{13}$ and many surgeons feel uncomfortable with the vaginal route in the absence of prolapse. Laparoscopically assisted vaginal hysterectomy is a new technique which is currently under evaluation in a large trial and a nationwide observational study, both funded through the NHS R and D programme.

Should the cervix be removed during abdominal or laparoscopic hysterectomy? Surgical morbidity is often the result of removal of the cervix, which lies close to the ureters and bladder and from which it must be carefully dissected with a consequent risk of vault haematoma or urological injury. ${ }^{14}$ This, along with a suspicion that the presence of the cervix may enhance orgasm, has led to calls for "sub-total" hysterectomy. Removal of the cervix was strongly advocated in the first half of the century, in part because of the risk of cancer. However, the residual risk of this disease in women with a history of regular negative cervical smears is sufficiently low to be traded off against lower complication rates. ${ }^{14}$

What about other surgical alternatives? Various techniques to remove the endometrium while leaving the remainder of the uterus in situ have been investigated. ${ }^{15}$ Although these procedures result in lower morbidity and shorter hospital stay than hysterectomy, up to $30 \%$ of patients will eventually lose their uterus. Endometrial surgery provides additional choice, but overall rates of surgical treatment have not declined and may have risen. ${ }^{16}$

About one woman in seven will decline hysterectomy if she can be shown to have blood loss within the normal range. ${ }^{17}$ For these and other women, medical treatments are appropriate. However, referral is almost always followed by surgery, ${ }^{18}$ and medical treatments may merely delay a surgical "solution." The new progesterone-coated intrauterine device proposes to revolutionise non-surgical management. Recently licensed in this country, the levonorgestrel-bearing device substantially reduces menstrual flow (and seems to be much more effective than oral medical treatment) while also providing effective contraception and reducing the risk of sexually transmitted diseases. ${ }^{19}$ Whether this will remove hysterectomy from its pre-eminent place in the repertoire of gynaecological treatments remains to be seen. Although the first hysterectomy was carried out in 1822, ${ }^{20}$ it has become a mainstay of gynaecological practice. It is quite probable that the operation has "peaked" and will now decline in incidence. There is no "correct" hysterectomy rate, but "correct" practice is to make explicit the trade offs between this operation and an increasing number of alternatives.

I thank Professors Angela Coulter, Klim McPherson, James Drife, and Nicholas Johnson for help with this article.

R J Lilford

Professor of health services research

Department of Public Health,

Faculty of Medicine,

The University of Birmingham,

Edgbaston, Birmingham B15 2TT

1 Coulter A, McPherson K. The hysterectomy debate. Q J Soc Aff 1986;2:379-96.

2 Fraser IS, Pearse C, Shearman RC, Elliot PM, McIlveen J, Markham R. Efficacy of mefenamic acid in patients with a complaint of menorrhagia. Obstet Gynecol 1981:58:543-51.

3 Kuh D, Stirling S. Socioeconomic variation in admission for diseases of female genital system and breast in a national cohort aged 15-43. BMJ 1995;311:840-3.

4 Coulter A, Peto V, Doll H. Influence of sex of general practitioner on management of menorrhagia. BrJ Gen Pract 1995;45:471-5.

5 Wennburg JE, McPherson K, Caper P. Will payment based on diagnosis related groups control hospital costs? N Engl J Med 1984;311:295-300.

6 Bunker JP, Brown BW. The physician-patient as an informed consumer of surgical services. N Engl J Med 1974;290:1051-5.

7 Domenighetti G, Luraschi P, Casabianca A, Gutzwiller F, Spinelli A, Pedrinis E, et al. Effect of information campaign by the mass media on hysterectomy rates. Lancet 1988;ii:1470-3.

8 Nathorst-Boos J, von Schoultz B, Carlstrom K. Elective ovarian removal and estrogen replacement therapy-effects on sexual life, psychological well-being and androgen status. J Psychosom Obstet Gynecol 1993;14:28393.

9 Griffith-Jones MD, Jarvis GJ, McNamara HM. Adverse urinary symptoms after total hysterectomy-fact or fiction. BMJ 1991;67:295-7.

10 Wingo PA, Hueze CM, Rubin GL, Ory HW, Peterson HB. The mortality risk associated with hysterectomy. Am J Obstet Gynecol 1985;152:803-8.

11 Sandberg SI, Barnes BA, Weinstein MC, Braun P. Elective hysterectomy: benefits, risks and costs. Med Care 1985:23:1067-85.

12 Casey MS, Garcia-Padial J, Johnson C, Osborne MG, Satolongo J, Wabor P. A critical analysis of laparoscopic assisted vaginal hysterectomies compared with vaginal hysterectomies. J Gynaecol Surg 1994;10:7-14.

13 Johnson N. Urological and bowel injuries with laparoscopically assisted hysterectomies. J Gynaecol Surg (in press).

14 Drife J. Conserving the cervix at hysterectomy. Br J Obstet Gynaecol 1994;101:563-4.

15 Sculpher M, Bryan S, Dwyer N, Hutton J, Stirrat GM. An economic evaluation of transcervical endometrial resection versus abdominal hysterectomy for the surgical treatment of menorrhagia. Br J Obstet Gynaecol 1993; 100:237-43.

16 Bridgeman SA. Trends in endometrial ablation and hysterectomy for dysfunctional uterine bleeding, in Mersey region. Gynaecological Endoscopy 1996;5:5-8.

17 Gannon MJ, Day P, Hammadieh N, Johnson N. A new method for measuring menstrual blood loss and its use in screening women before endometrial ablation. Br J Obstet Gynaecol (in press).

18 Coulter A, Kelland J, Peto V, Rees MCP. Treating menorrhagia in primary care. Int J Technol Assess Health Care 1995;11:456-71.

19 Luukhainen T, Toivonen J. Levenorgestrel-releasing IUD as a method of contraception with therapeutic properties Contraception 1995-59-269-76.

20 O'Dowd MJ, Philipp E. The history of obstetrics and gynaecology. London: Parthena Publishing, 1994: 302, 409. 


\title{
Drinking before sedation
}

\author{
Preoperative fasting should be the exception rather than the rule
}

$\mathrm{T}$ Traditionally, patients are starved of food and fluid for several hours before being given a general anaesthetic. However, in the early days of anaesthesia a drink was often recommended before the procedure, ${ }^{1}$ and a fluid fast became commonplace only after the publication of Mendelson's landmark study in 1946. ${ }^{2}$ In it he described the risk of gastric acid aspiration during obstetric anaesthesia with the consequent development of pneumonitis. He also showed that human gastric acid injected into the airway of rabbits caused radiographic changes similar to those described after acid aspiration in pregnant women.

The findings of these studies have since been extrapolated to all forms of general anaesthesia, resulting in patients being deprived of fluid from midnight before a morning anaesthetic and allowed only a light breakfast before afternoon surgery. Furthermore, with increasing numbers of patients undergoing invasive procedures requiring intravenous sedation, the "nil by mouth from midnight" request has spread to medical wards. In particular, patients are starved before elective gastroscopy, endoscopic retrograde cholangiopancreatography, and colonoscopy. However, this prolonged fast of fluid is illogical for two reasons: firstly, in fasting patients the stomach can secrete up to $50 \mathrm{ml}$ of gastric juice an hour; ${ }^{3}$ and secondly, it has been shown that ingested clear fluids rapidly leave the stomach of healthy people, with about half the volume disappearing in 10-20 minutes. ${ }^{4}$

Recently, workers have questioned the benefits of a fluid fast before anaesthesia. Prolonged fluid deprivation has been shown to increase the volume and decrease the $\mathrm{pH}$ of gastric juice, both of which increase the likelihood and consequences of gastric acid aspiration. Sutherland $e t$ al used an orogastric tube to measure the volume and $\mathrm{pH}$ of gastric juice in 100 anaesthetised patients who were randomly assigned either to drink $150 \mathrm{ml}$ of water two to three hours before their anaesthetic or to fast from midnight $t^{5}$ : the volume and $\mathrm{pH}$ of residual gastric juice was $20.6 \mathrm{ml}$ and 2.05 respectively in the patients who drank compared with $29.9 \mathrm{ml}$ and 1.72 in the patients who fasted.

The same group has since repeated the study and shown that the volume and $\mathrm{pH}$ of residual gastric contents of 300 consecutive patients randomised to drink $150 \mathrm{ml}$ of coffee or orange juice given with ranitidine three hours before anaesthesia were identical to those in patients who did not drink. ${ }^{6}$ In that study the patients who drank suffered less thirst compared with those who did not. A further randomised controlled study by Phillips et al showed similar residual gastric volumes and $\mathrm{pH}$ in 100 patients starved conventionally (19 $\mathrm{ml}$ and 2.26 respectively) or allowed unrestricted intake of clear fluid until two hours before their anaesthetic (22 $\mathrm{ml}$ and 2.64$){ }^{7}$

In response to these studies the Canadian Anaesthetists' Society produced guidelines stating that a fluid fast of more than three hours is unnecessary in healthy patients undergoing surgery. ${ }^{8}$ Furthermore, gastroscopy has been used to visualise and aspirate all gastric juice in sedated patients undergoing gastroscopy and has validated the previous studies in which orogastric tubes were used to obtain stomach fluid. Eighty eight patients were randomised to drinking either $330 \mathrm{ml}$ of water two hours before their endoscopy or an overnight fast. ${ }^{9}$ After oesphageal intubation, all gastric juice was aspirated and the volume and $\mathrm{pH}$ measured and found to be virtually identical in the two groups. In addition, mucosal views were excellent in all the examinations.

Although patients who are likely to have delayed gastric emptying (through underlying disease or drug treatment) should not drink before anaesthesia or intravenous sedation, there is now overwhelming evidence in favour of allowing patients who fulfill grades I or II of the American Society of Anesthesiologists classification of physical status to drink clear fluids up to two hours before the procedure. This message should now be disseminated to all medical and nursing staff to ensure that patients do not suffer uncomfortable thirst and that their procedure is not cancelled because of an inadvertent drink.

S M Greenfield Consultant gastroenterologist

Department of Gastroenterology,

Queen Elizabeth II Hospital,

Welwyn Garden City,

Hertfordshire AL7 4HQ

G J M Webster Specialist registrar

Department of Medicine,

Royal Free Hospital School of Medicine,

London NW3 2PF

F R Vicary

Consultant physician

Department of Gastroenterology,

Whittington Hospital,

London N19 5SF

1 Lister J. On anaesthetics, part IIII. In: Holmes'system of surgery. Vol 3, 3rd ed. London: Longmans Green and Company, 1883. (Reprinted in: The collected papers of Joseph Lister. Birmingham: Classics of Medicine Library, 1979: 171-2).

2 Mendelson CL. The aspiration of stomach contents into the lungs during obstetric anesthesia. Am J Obstet Gynecol 1946;52:191-205.

3 Guyton AC. Textbook of medical physiology. 7th ed. Philadelphia: WB Saunders, 1986: 774-8.

4 Hunt JN, Spurrell WR. The pattern of emptying of the human stomach.J Physiol 1951;113:157-68.

5 Sutherland AD, Maltby JR, Sale JP, Reid CRG. The effect of preoperative oral fluid and ranitidine on gastric fluid volume and $\mathrm{pH}$. Can J Anaesth 1987;34:117-21.

6 Hutchinson A, Maltby JR, Reid CRG. Gastric fluid volume and pH in elective inpatients. Part l: coffee or orange juice versus overnight fast. Can J Anaesth 1988;35:12-5.

7 Phillips S, Hutchinson S, Davidson T. Preoperative drinking does not affect gastric contents. Br J Anaesth 1993;70:6-9.

8 The shortened fluid fast and the Canadian Anaesthetists' Society's new guidelines for fasting in elective/emergency patients. Can J Anaesth 1990;37:905-6.

9 Greenfield SM, Webster GJM, Brar A, Kuan AM, Beck ER, Vicary FR. Assessment of residual gastric volume and thirst in patients who drink before gastroscopy. Gut 1996;39:360-2. 


\title{
Non-invasive ventilation for acute exacerbations of chronic obstructive pulmonary disease
}

\author{
Use it soomer rather than later to assist the "respiratory muscle pump"
}

$\mathrm{B}$ etween a fifth and a third of patients admitted to hospital with hypercapnic respiratory failure secondary to acute exacerbation of chronic obstructive pulmonary disease will die in hospital, despite selective use of mechanical ventilation. ${ }^{1-13}$ In severe chronic obstructive pulmonary disease, hyperinflation places the respiratory muscles at a mechanical disadvantage and they function close to their maximum capacity. ${ }^{14} 15$ During acute exacerbations, elastic and resistive loads on the respiratory muscles increase and may lead to ventilatory failure. The ensuing tissue acidosis further impairs respiratory muscle function, producing a vicious cycle. ${ }^{16}$ Thus a logical approach is to assist the compromised "respiratory muscle pump".

Non-invasive positive pressure ventilation (NIPPV) employs a nasal or full face mask to administer ventilatory support from a flow generator and is established in the treatment of patients with a variety of chronic hypoventilatory syndromes. A role in acute exacerbation of chronic obstructive pulmonary disease (COPD) was suggested by early open and case control studies ${ }^{9-11}$ and has recently been confirmed by three randomised controlled trials (see table). ${ }^{5-7}$

Bott $e$ al randomised 60 patients with exacerbations of chronic obstructive pulmonary disease to either standard treatment (antibiotics, bronchodilators, corticosteroids, respiratory stimulants, and oxygen) or standard treatment plus non-invasive ventilation on a medical ward. ${ }^{5}$ Nine of the 30 patients receiving standard treatment died in contrast to only one of the 26 who accepted non-invasive ventilation (relative risk 0.13, 95\% CI 0.02-0.95). (Of the four who did not receive ventilation, two died.) Four patients who failed to respond to standard treatment were offered noninvasive ventilation, though three required intubation.

Brochard et al selected 85 patients with incipient acute respiratory failure from a pool of 275 and treated 42 with standard therapy and 43 with additional noninvasive ventilation. ${ }^{6}$ Patients were excluded if they needed immediate intubation, had heart failure, pneumonia, asthma, or sepsis, or were postoperative. In the standard treatment group, $74 \%$ were intubated and $29 \%$ died compared with 26\% $(\mathrm{p}<0.001)$ and $9 \%$ $(\mathrm{p}=0.02)$ respectively in the ventilated group. Furthermore, life threatening complications were more frequent in the standard treatment group and hospital stay was longer (see table) ${ }^{6}$

In a well matched group of patients, Kramer et al found a significant reduction in the need for intubation in patients treated with non-invasive ventilation (one of 11) over those receiving standard treatment (eight of 12). ${ }^{7}$ Mortality was lower than in the other studies and may reflect sample size, the intensive care setting, or longer duration of ventilation.

Although these studies seem conclusive, they could not be blind since "sham" ventilation is not feasible. Significant placebo effect and bias in management may have influenced the outcome. In two of the studies, investigators making clinical management decisions were unaware of which treatment arm a patient was in until ventilation was started, ${ }^{5}$ and in the third the decision to intubate was not made by the investigators. ${ }^{7}$ The lack of a clear protocol for establishing the need for intubation is therefore a weakness in two of the studies since it allows management bias, and although Brochard et al clearly specified criteria for intubation, they were complex. $^{6}$ In two studies significant reductions in breathlessness scores and respiratory rate were found in the ventilated groups. ${ }^{5}$ However, breathlessness was measured by visual analogue scale rather than validated questionnaire. One recent controlled study has shown no beneficial effect of non-invasive ventilation given twice a day for three hours, but patients were less severely affected than in other studies since all recovered without the need for mechanical ventilation. ${ }^{17}$

Both the initial response to non-invasive ventilation and the severity of the ventilatory failure at presentation are important predictors of success. Ambrosino et al

\begin{tabular}{|c|c|c|c|}
\hline Entry criteria & Exclusion criteria (selected) & Main findings (Standard $v$ NIPPV) & Comment on study \\
\hline \multicolumn{4}{|l|}{ Bott et al ${ }^{5}$} \\
\hline $\begin{array}{l}\text { Clinical diagnosis of chronic airflow } \\
\text { obstruction and: } \\
\mathrm{PaO}_{2}<7.5 \mathrm{kPa} \\
\mathrm{PaCO}_{2}>6 \mathrm{kPa} \\
\mathrm{Age} \leq 80 \text { years }\end{array}$ & $\begin{array}{l}\text { Severe non-respiratory disease, } \\
\text { prior NIPPV }\end{array}$ & $\begin{array}{l}\text { Reduced mortality ( } 30 \% \text { v } 4 \%, P=0.014) \\
\text { Reduced breathlessness }\end{array}$ & $\begin{array}{l}\text { No objective criteria for intubation } \\
\text { Non-validated dyspnoea } \\
\text { questionnaires }\end{array}$ \\
\hline \multicolumn{4}{|l|}{ Brochard et $a l^{6}$} \\
\hline $\begin{array}{l}\text { Increased dyspnoea for }<2 \text { weeks and: } \\
\mathrm{PaO}_{2}<6.0 \mathrm{kPa} \\
\mathrm{pH}<7.35 \\
\text { Respiratory rate }>30 \text { breaths } / \text { min }\end{array}$ & $\begin{array}{l}\text { Respiratory rate }<12 \text { breaths/min, } \\
\text { need for immediate intubation, } \\
\text { asthma, heart failure, } \\
\text { pneumothorax, sepsis, } \\
\text { postoperative period }\end{array}$ & $\begin{array}{l}\text { Reduced mortality ( } 29 \% \vee 9 \%, \mathrm{P}=0.02) \\
\text { Reduced intubation }(74 \% \vee 26 \%, \mathrm{P}<0.001) \\
\text { Reduced hospital stay ( } 35 \text { days } \vee 23 \text { days, } \\
\mathrm{P}=0.02) \\
\text { Reduced life threatening complications } \\
\quad(48 \% \vee 16 \%, \mathrm{P}=0.001)\end{array}$ & $\begin{array}{l}\text { Carefully selected population } \\
\text { Detailed criteria for intubation } \\
\text { Sealed envelopes used for } \\
\text { treatment allocation }\end{array}$ \\
\hline \multicolumn{4}{|l|}{ Kramer et al ${ }^{7}$} \\
\hline $\begin{array}{l}\text { Moderate to severe dyspnoea and: } \\
\mathrm{PaCO}_{2}>6 \mathrm{kPa} \\
\mathrm{pH}<7.35 \\
\text { Respiratory rate }>24 \text { breaths } / \mathrm{min}\end{array}$ & $\begin{array}{l}\text { Need for immediate intubation, } \\
\text { inability to cooperate or fit mask, } \\
\text { inability to clear secretions, } \\
\text { uncontrolled arrhythmias, systolic } \\
\text { blood pressure }<90 \mathrm{~mm} \mathrm{Hg}\end{array}$ & $\begin{array}{l}\text { Reduced intubation }(73 \% \vee 31 \%, \mathrm{P}<0.05) \\
\text { Reduced breathlessness } \\
\text { Reduced respiratory rate at } 1 \text { hour }\end{array}$ & $\begin{array}{l}\text { Non-validated dyspnoea } \\
\text { questionnaires } \\
\text { Lower mortality-may reflect } \\
\text { intensive care setting }\end{array}$ \\
\hline
\end{tabular}


found that at one hour the blood $\mathrm{pH}$ was lower and $\mathrm{PaCO}_{2}$ higher in patients in whom non-invasive ventilation would be unsuccessful. Rapid improvement in $\mathrm{pH}$ and respiratory rate in the first hour of non-invasive ventilation has been shown to be an important predictor of success. ${ }^{5}{ }^{17}$ Reversing the vicious cycle of ventilatory failure and acidosis is likely to be easier at an earlier stage since the level of assistance required may be less both in terms of time using the ventilator and magnitude of pressure support. Furthermore, other consequences of hypoventilation, such as mucus retention, are less likely. Thus non-invasive ventilation should be instituted at an early stage when the $\mathrm{pH}$ falls below $7.35^{56}$ and the respiratory rate exceeds 30 breaths per minute. If there is no improvement in these parameters in the first one to two hours, intubation should be considered. ${ }^{5}{ }^{18}$ Two studies have shown that the more severe the episode of ventilatory failure (indicated by the degree of acidosis) the smaller the chances of success. ${ }^{68}$ Non-invasive ventilation cannot be recommended for patients who require immediate intubation because none of the controlled trials included such patients. The duration of ventilation will depend on need and tolerance, but in two controlled trials a mean of only six to eight hours per day was efficacious. ${ }^{5}{ }^{6}$

1 Moser KM, Luchsinger PC, Adamson JS, McMahon SM, Schlueter DP, Spivack KM, et al. Respiratory stimulation with intravenous doxapram in respiratory failure. A double-blind co-operative study. N EngJ Med 1973; 288: 427-31.

2 Kettel LJ, Diener CF, Morse JO, Stein HF, Burrows B. Treatment of acute respiratory acidosis in chronic obstructive lung disease. JAMA 1971; 217 : 1503-8.

3 Warren PM, Flenley DC, Millar JS, Avery A. Respiratory failure revisited; acute exacerbations of chronic bronchitis 1961-68 and 1970-76. Lancet 1980; I: 467-71.

4 Jeffrey AA, Warren PM, Flenley DC. Acute hypercapnic respiratory failure in patients with chronic obstructive lung disease; risk factors and use of guidelines for management. Thorax 1992; 47: 34-40.

5 Bott J, Carroll MP, Conway JH, Keilty SEJ, Ward EM, Brown AM, et al. Randomised controlled trial of nasal ventilation in acute ventilatory failRandomised controlled trial of nasal ventilation in acute ventilatory fail-
ure due to chronic obstructive airways disease. Lancet 1993; 341: 1555-7.

6 Brochard L, Mancebo J, Wysocki M, Lofaso F, Conti G, Rauss A, et al. Non-invasive ventilation for acute exacerbations of chronic obstructive pulmonary disease. N Eng J Med 1995; 333: 817-22.

7 Kramer N, Meyer TJ, Meharg J, Cece RD, Hill NS. Randomized, prospective trial of non-invasive positive pressure ventilation in acute respiratory failure. Am J Resp Crit Care Med 1995; 151: 1799-806.

8 Ambrosino N, Foglio K, Rubini F, Clini E, Nava S, Vitacca M. Non-invasive mechanical ventilation in acute respiratory failure due to chronic obstructive pulmonary disease; correlates for success. Thorax 1995; 50: 755-7.

9 Meduri GU, Conoscenti CC, Menashe P, Nair S. Non-invasive face mask ventilation in patients with acute respiratory failure. Chest 1989;95:865-70.
Which health professionals should initiate noninvasive ventilation is not clear, but the list may include pulmonary function technicians, physiotherapists, nurses, and junior medical staff, depending on local interest and expertise. Nursing staff under medical guidance should probably play a major role, especially as a 24 hour service is required. Earlier reports that non-invasive ventilation was time consuming for nursing staff ${ }^{13}$ have not been confirmed. ${ }^{57}$

A trial of non-invasive ventilation should be considered early in the course of acute respiratory failure secondary to exacerbation of chronic obstructive pulmonary disease as a means of avoiding intubation and reducing hospital stay and mortality.

David R Baldwin

Consultant physician

Department of Respiratory Medicine,

Nottingham City Hospital,

Nottingham NG5 1PB

Martin B Allen Consultant physician

Sleep and Ventilation Centre,

Department of Respiratory Medicine,

City General Hospital,

Stoke on Trent ST4 6QG

10 Foglio C, Vittaca M, Quadri A, Scalvini S, Marangoni S, Ambrosino N. Acute exacerbations in severe COLD patients: treatment using positive pressure ventilation by nasal mask. Chest 1992; 101: 1533-8.

11 Brochard L, Isabey D, Piquet J, Amaro P Mancebo J, Messadi A-A, et al. Reversal of acute exacerbations of chronic obstructive lung disease by inspiratory assistance with a face mask. N Eng J Med 1990; 323: 1523-30.

12 Meecham-Jones DJ, Paul EA, Grahame-Clarke C, Wedzicha JA. Nasal ventilation in acute exacerbations of chronic obstructive pulmonary disease: effect of ventilator mode on arterial blood gas tensions. Thorax 1994; 49: 1222-4.

13 Chevrolet JC, Jolliet P, Abajo B, Toussi A, Lois M. Nasal positive pressure ventilation in patients with acute respiratory failure is a difficult and time consuming procedure for nurses. Chest 1991; 100: 775-82.

14 Tobin MJ, Perez W, Guenther SM, Semmes BJ, Madar MJ, Allen SJ, et al. The pattern of breathing during successful and unsuccessful trials of weaning from mechanical ventilation. Am Rev Respir Dis 1986; 134: 1111-8.

15 Macklem PT. Hyperinflation. Am Rev Respir Dis 1984; 129: 1-2.

16 Jaun G, Calverley P, Talamo C, Schnader J, Roussos C. Effect of carbon dioxide on diaphragmatic function in human beings. N Eng J Med 1984; 310:874-9.

17 Barbe F, Togores B, Rubi M, Pons S, Maimo A, Agusti A. Noninvasive ventilatory support doses not facilitate recovery from acute respiratory failure in chronic obstructive pulmonary disease. Eur Respir J 1996;9:1240-5.

18 Meduri GU, Turner RE, Abou-Shala N, Wunderink R, Tolley E. Noninvasive positive pressure ventilation via face mask. Chest 1996;109:179-93.

\section{Don't treat shackled patients}

\section{And keep trying to understand what the Nuremberg trials taught us}

$\mathrm{L}$ ast week Britain was shocked by the report of a young man who was shackled to a bed until two shackled because he was a prisoner. Last year doctors and others had to protest about women prisoners being forced to give birth while shackled. ${ }^{1}$ Understandably doctors unused to treating prisoners in NHS hospitals are not sure about "the rules." But they should be. Doctors should simply refuse to treat patients who are shackled, and doctors' organisations should support them without quibble. This is the state making doctors participate in unethical acts in the way that was described in the BMJ's December 7 issue marking the 50th anniversary of the Nuremberg doctors' trials.

Richard Smith

Editor

$B M J$,

London WC1H 9JR

1 Dillner L. Shackling prisoners in hospital. BMJ 1996;312:200. 